New Zealand Journal of Industrial Relations, 1982, 7 179-181

\title{
Unemployment and redundancy: a union viewpoint
}

\author{
Rob Campbell*
}

The fact that unemployment and the threat of unemployment are two of the major issues facing unions was underlined by an historic first joint conference convened in August 1981 by the Federation of Labour and the Combined State Unions. The present level of unemployment, and the magnitude of potential changes in the labour market over the next decade or so, pose challenges to union organisation just as great as the more immediate problems of maintaining wages levels and working conditions. Since that Conference there has been a series of industrial disputes over aspects of job security both in the private and in the state and local body sectors.

From the union standpoint, unemployment is one of the many symptoms of crisis in our society. That symptom has some factors which isolate it from the others, particularly for those individuals subjected to a long period of joblessness. But the problems of change in the structure of our economy, the pace of which is quickening and the impact of which is so adverse for many of our members, are an ever present danger to unions.

Look at the range of impacts associated with the general problem:

(1) The redundancy impact: where workers are denied the right to jobs because of market, managerial or political decisions which are quite outside of their control;

(2) The unemployment impact: the problem of lack of jobs for new entrants to the labour market or those who have lost jobs previously held;

(3) The associated impact of casualisation: the same pressures and changes which are causing unemployment are generating the split of more jobs into part-time, temporary, or sub-contracted jobs and destroying employment security;

(4) The insecurity and divisiveness impact: the development of fear of unemployment as a means of labour control has become a real factor in industrial relations; this can be particularly divisive as various groups are "blamed" and competitive rather than co-operative attitudes harden within the workforce.

As unions we are painfully aware of this full range of impacts. It is not hard for us to see that the campaign to lower youth rates has its base in unemployment, that the aggressive reaction to wage demands designed to simply maintain real wages has the same base; that redundancy disputes are more and more prominent as the opportunity for new jobs diminishes.

Because of our direct involvement in all of these aspects of the economic crisis, from the about-to-be-employed worker, to the worker who is unemployed, to the worker whose job conditions or pay are threatened by unemployment, unions are central to the fight against unemployment.

Let me identify some of the main aspects of the developing union response.

(1) Although we are in the first instance responsible to our members, that commitment is recognised as including a responsibility to fight for and protect the interests of those who are not members simply because they cannot find work.

\footnotetext{
* Union advocate. This article was written before the imposition of limits of redundancy pay in July 1982.
} 
(2) We must recognise that apart from our ability to politically influence national decision-making, we are much less able to work in the interests of unemployed workers if only because they are not organised in terms of our base at the workplace. This means that new and different methods of organising unemployed workers must be found within the general umbrella of the union movement. In fact the district trade councils of the FOL have made a fair proportion of their meagre resources available for this task. But with the new methods used for the hand-out of social welfare payments by cheque, there are no longer the congregations of unemployed previously associated with high levels of unemployment. These problems are compounded by the high degree of unemployment amongst young workers many of whom have never been unionised and therefore do not see unions as an appropriate point of reference.

(3) We must pay even greater attention (where we are able) to fighting redundancy situations in such a way as to maintain employment. There is a major need in this area for much improved procedures industrially for early notification and full disclosure of information by the employer. This is not to belittle the importance of adequate redundancy compensation where necessary but rather to emphasize the need for employment protection agreements of broader scope than most redundancy agreements.

It has become commonplace for employer circles to bemoan the level of redundancy payments. These vary in practice from nil to relatively generous amounts. The Labour Party has called for legislation in this area, but unions have continued to adopt the view that redundancy compensation is a matter which should be negotiated on an industry; not economy-wide basis.

The Labour Party proposals have envisaged a national level of redundancy pay. While laudable in theory, such a level seems doomed to fail. With the present guidelines in the Wage Adjustment Regulations offering neither guarantee of redundancy pay nor any kind of effective limitation, a more realistic, legislated level of redundancy pay has some attraction. A "six and two" system has become quite common (six weeks pay for the first year of service and two weeks for each year thereafter) following a major manufacturing house agreement which set a "three and one" level that spread throughout the country. Any legislated level would have to meet at least this level to have any chance at all of acceptance. Yet again this is far above the levels envisaged in some industries.

The Labour Party has also suggested a fund for redundancy payments which could have some equalising effect. Such a fund would, of course, improve the lot of both some workers (who otherwise get nothing) and some employers (whose obligations would be less than those currently met on an ad hoc basis). Suggestions that unions might contribute to such a fund have predictably met with a stony response from unions which quite properly adopt the view that it is not their function in life to subsidise unsuccessful business decisions.

(4) Unions can play a part in alternative work schemes, and should do so, but recognise two aspects of such schemes:

(a) while a valid choice for some people, such schemes are not an "answer" to unemployment on present or projected future scales;

(b) such schemes must be consistent with levels of pay and working conditions fought for by unions and not be capable of misuse by private or public employers to undercut such conditions.

(5) Industries which have the technological and productive level to sustain a shorter working week or working year should negotiate agreements for such change. Such 
agreements should be designed to increase or stabilise employment levels and not simply to increase earnings. This was the approach adopted by unions in the freightforwarding, oil, meat and metal industries in 1981.

These approaches met with a quite hysterical response from both employer groups and the Government. Such responses have refused to accept the possibility put forward by unions that each industry should be viewed as a separate entity in these matters and have responded to the impact seen as likely from an economy-wide movement to shorter working hours. This is an area in which the industrial relations system has shown both inflexibility and immaturity and this, in turn, has contributed to levels of unemployment.

(6) Part-time work and other flexible arrangements have an attraction for some workers. These should be seen as additional work demands rather than as replacements for full-time present jobs. This area of demand for jobs has also to be seen in the context of the adequacy of child-care facilities. Industries which have had ready opportunities under awards and agreements for part-time, casual or similar work arrangements (such as retailing) have seen an excessive use of such opportunities to suit employer, rather than worker, interests.

(7) In assisting unemployed workers and organisations of such workers, emphasis must be placed on increasing the level of unemployment wages and the improvement of facilities for training and the search for jobs.

However, all of these approaches are a defensive reaction to the fact of unemployment. The main emphasis of the union approach is to state that the responsibility for unemployment must be properly identified. This must be done not so much to allocate blame as to accurately state the problem and promote an appropriate solution.

The only answer to unemployment is jobs. Jobs can only be created in a stable, growing, ecologically and economically balanced economy. The answer can be produced not by a "growth strategy" but by an "employment strategy" which places employment creation as its main priority. That is a political question but one which, as unions, we can't afford to ignore.

Don't look to unions, any more than you should look to unemployed workers, to solve the problems of unemployment.

Don't even look to employers. There are selfish and callous employers and no doubt you find kind and socially concerned employers. But they are in business to make a profit and not to give away jobs. They can in certain circumstances be forced to maintain employment and this is quite proper but apart from the large monopolies they do not control the destiny of their own operations.

The responsibility must be political. The state exercises general management of the economy and must be accountable for ensuring that the economy acts in a socially responsible manner. We are aware of the extent to which economic power is exercised by external interests which control supplies to our country, the markets for our products and large parts of our own production and distribution systems. More effective social control of the economy is an urgent priority.

The recent unemployment conference concluded:

The demands of the labour movement are not extreme demands. We require a structure of economy and society in which all those who are looking for paid employment have access to secure jobs at reasonable rates of pay and under safe and acceptable conditions of employment.

It is because we recognise that the present government and the present system will not give us these demands that the issues surrounding unemployment in all of its aspects have come to the forefront of union organisation. 